University of Rhode Island

DigitalCommons@URI

The Rhode Island Current Conditions Index

Economics

$1-2010$

\title{
Rhode Island Current Conditions Index - January 2010
}

Leonard Lardaro

University of Rhode Island, lardaro@uri.edu

Follow this and additional works at: https://digitalcommons.uri.edu/ricci

Part of the Econometrics Commons

Terms of Use

All rights reserved under copyright.

\section{Recommended Citation}

Lardaro, Leonard, "Rhode Island Current Conditions Index - January 2010" (2010). The Rhode Island Current Conditions Index. Paper 3.

https://digitalcommons.uri.edu/ricci/3

This Article is brought to you for free and open access by the Economics at DigitalCommons@URI. It has been accepted for inclusion in The Rhode Island Current Conditions Index by an authorized administrator of DigitalCommons@URI.For more information, please contact digitalcommons-group@uri.edu. 
The recently released labor market revisions for 2009 were consistent with the conjectures I made in the past few $\mathrm{CCl}$ reports. Payroll employment was indeed revised down, and Rhode Island's Unemployment Rate never reached 13 percent, as the mid-2009 jump in our Labor Force was revised away. These data revisions did impact two of the $\mathrm{CCl}$ values released along the way: both June and July of 2009 were revised down, as the Labor Force actually fell in those months compared to a year ago, reversing the increases stated in the original data.

Rhode Island begins 2010 with a Current Conditions Index value of 33, as only four of the twelve indicators improved in January. But as values of 33 go, this was a fairly strong result. First, the $\mathrm{CCl}$ is derived from year-over-year changes, so compared to a year ago, most indicators are still at somewhat depressed levels. So it is also necessary to focus on monthly changes. For January, eight of the twelve $\mathrm{CCl}$ indicators either improved or were very close to improving. Second, Lanuary marked the ninth consecutive month for which the $\mathrm{CCl}$ beat its year-earlier value. Finally, while January's CCl value of 33 may seem disappointing, one year ago, it was only 17 !

So, at the two and a half year mark for Rhode Island's current recession, its economy continues to have a pulse, its momentum is moving in the right direction, and there is no basis upon which to reject the expectation of a recovery sometime in 2010. I continue to anticipate a recovery that begins by mid-year, but I am a bit little less confident in that expectation than I was before the data revisions.

\begin{tabular}{|l|c|}
\hline \multicolumn{2}{|c|}{ CCI Indicators - \% Change } \\
\hline Government Employment & -1.9 \\
\hline US Consumer Sentiment & 21.9 Y \\
Single-Unit Permits & 123.6 Y \\
Retail Sales & -2.8 \\
\hline Employment Services J obs & -7.4 \\
Priv. Serv-Prod Employment & -2.1 \\
\hline Total Manufacturing Hours & -8.5 \\
\hline Manufacturing Wage & $2.3 \mathbf{Y}$ \\
\hline Labor Force & 2.2 Y \\
Benefit Exhaustions & 9.0 \\
\hline New Claims & 17.3 \\
\hline Unemployment Rate & 32.3 \\
\hline \multicolumn{2}{|c|}{ Y= I mproved Value } \\
\hline
\end{tabular}

Looking at the January $\mathrm{CCl}$ performance, US Consumer Sentiment continued to be our "star" performer, rising by 21.9 percent in January, its tenth consecutive year-over-year improvement. Our state's Labor Force rose again, increasing by a surprising 2.2 percent compared to a year ago. Growth in the Manufacturing Wage remained rapid in January, a 2.3 percent rate, sustaining a string of growth rates above 2 percent since last September. The other improving indicator, Single-Unit Permits, has been extremely volatile of late. In spite of the fact that there continues to be virtually no new home construction in Rhode Island, Single-Unit Permits rose by 123.6 percent compared to last January, when there were only 26 permits for the entire state.

It wasn't difficult to find negatives in January's performance. Retail Sales fell by 2.8 percent in January, no doubt partly related to weather conditions. Future job prospects based on Employment Service Jobs, a leading indicator, remained discouraging, as these fell 7.4 percent compared to a year ago. In spite of this decline, this indicator has stabilized on a monthly basis since last March. Total Manufacturing Hours fell again, but by a less than double-digit rate ( 8.5 percent) compared to last year. The good news is that it actually rose on a monthly basis for only the fourth time since 2007. Private Service-Producing Employment declined again, by 2.1 percent, reflecting the grim job prospects here, and a repeat of our 12.7 percent Unemployment Rate. Government Employment, driven largely by budget woes, declined by 1.9 percent in January. Finally, Benefit Exhaustions, which reflects long-term unemployment, rose by "only" 9 percent, while New Claims, a leading indicator that measures layoffs, rose by 17.3 percent, breaking a string of six improvements in the last seven months.

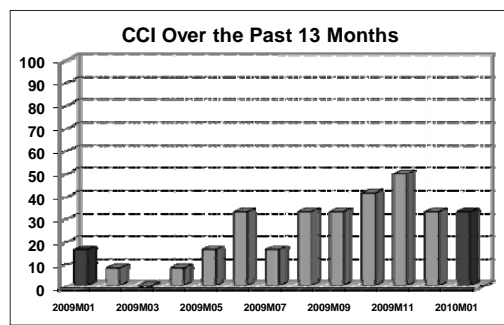

\section{THE BOTTOM LINE}

Rhode Island has now been in a recession for two and a half years. While the worst of the cyclical problems appear to be behind us, we should be taking specific steps that will determine the velocity of our post-recession economic performance. Some say that "a crisis is a terrible thing to waste." Sadly, Rhode I sland has apparently wasted this crisis by its continued lack of action.

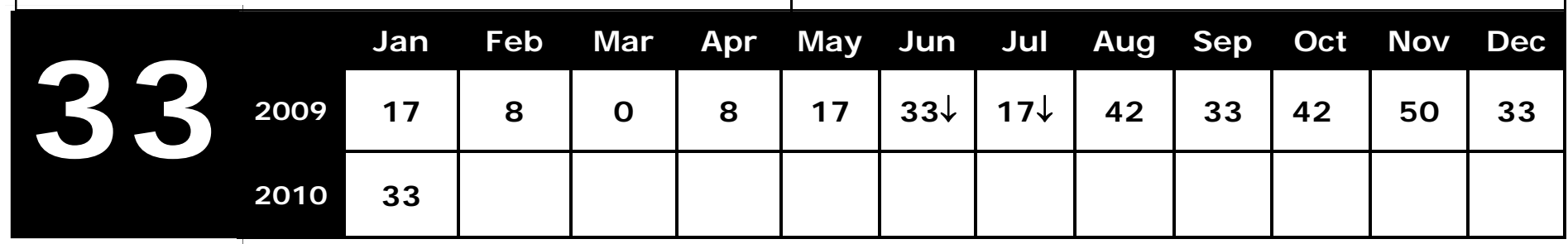

